a portrait of the late Sir John Thornycroft, and a commemoration medal of the late Prof. Auguste Rateau.

\section{Standardisation of Electric Frequency in Paris}

ONE of the difficulties in connexion with the nationalisation of the British system of electric supply is the fact that many large systems are using a different frequency of supply from the chosen standard of 50 . The discussion, therefore, on the standardisation of the frequency of electricity supply in Paris, held at the Institution of Electrical Engineers on Feb. 29, was a timely one. P. Rieunier exhibited a film which showed clearly how rapid the conversion had been. The Paris area extends in a circle of about thirty miles in radius around Paris. Before the War it was supplied at four different frequencies by various undertakings. In 1919 it was decided to build large modern steam-generating stations in Paris and connect them with a 60 kilovolt ring main around the city, which was also connected by transformers to the hydro-electric stations of the Central Plateau through the $120 \mathrm{kv}$. and $220 \mathrm{kv}$. mains. In addition, it was decided to create a national network at a frequency of 50 which could be converted into direct current at the highest possible voltage for the electrification of the railways. Instead of having a grid round the country as in England, connected with large and efficient generating stations, France has a series of lines radiating from the principal centres of consumption. In Paris the conversion of the two-phase to direct current is carried out by rotary converters and mercury arc rectifiers. On the 25 frequency network all motors are replaced either by new or second-hand motors having twice as many poles. On the $41 \frac{2}{3}$ frequency network the motors have been unchanged, but the mechanical units to which they are coupled have been adapted to work at a 20 per cent increase of frequency. Luckily the motors were originally manufactured in 50 frequency frames, so it was only necessary to speed them up to the figure for which they were originally designed. Difficulty was experienced in converting small motors such as those used for calculating machines and similar apparatus.

\section{Books for the Blind in the United States}

THE Report of the Library of Congress, Washington, D.C., for the year ending June 30, 1931, is a volume of 463 pages, which includes a review of the activities of its various divisions and gives much interesting information regarding the books and manuscripts acquired during the previous twelve months. The total number of books and pamphlets is now 4,292,288, as against 4,103,936 in June 1930 . "A new responsibility imposed upon us by legislation at the last session", says the report, "concerns the supply of books (in embossed type) for the blind." It is embodied in an Act approved on March 3, 1930, which makes an appropriation of 100,000 dollars to provide books for the use of adult blind residents of the United States. For some time past the Library has done notable work for the blind, and now has a collection of 22,655 books, periodicals, music, etc., mainly in Braille. During the year 1930-31 there were 3359 registered borrowers and 52,222 issues of books, etc. Of this number, 39,330 were works of fiction, 2758 histories, 2444 biographies, and 739 scientific works. With the American National Red Cross, the Library of Congress maintains a Braille transcribing service for the production of Braille manuseript. Lessons are arranged for, certificates of competency are granted, and manuscripts are prepared, bound, and distributed. During 1930-31, 247,708 pages of Braille were completed and, in book form, distributed among 53 institutions, libraries, and individuals. The students helped represented 34 colleges, high schools, and universities, and assistance was given to persons engaged in many callings. But great as is the service rendered, still more is required, and "no private gifts or public funds yet in sight can meet all the growing needs of touch readers"

\section{Biochemical Research in India}

THE Society of Biological Chemists in India, recently founded by the enterprise of certain members of the Department of Biochemistry of the Indian Institute of Science, Bangalore, has published a review of work carried out in India during 1930 ("Biochemical and Allied Research in India in 1930": Society of Biological Chemists, India). The Society was founded to co-ordinate the work carricd out in various parts of the country, and to arrange for the holding of meetings either of members of the Society alone or in association with other societies, for the exchange of ideas and the reading of papers. At present it is not proposed to issue a journal, although this may be practicable in the future as the volume of biochemical research increases. The present review, a pamphlet of twenty pages, deals with work on enzymes and fermentation, agricultural, dairy, plant, animal, and pharmaceutical and medicinal chemistry, nutrition and bacteriology. Reference is made to nearly a hundred original papers published during the year, which incidentally was the first working year of the new Imperial Council of Agricultural Research. The important work carried out by Chopra and his collaborators at the School of Tropical Medicine and Hygiene in Calcutta on the chemistry of Indian drugs, and by McCarrison at the Pasteur Institute, Coonoor, on nutritional problems is referred to, and the hope is expressed that workers will soon be attracted to the field of chemical and biological assay of drugs. The review indicates the rich field for research awaiting the attention of biochemists and pharmacologists in India.

\section{The Epithalassa of the Strait of Georgia}

These conditions have been described by $A$. Hutchinson and C. C. Lucas (Can. J. Research, vol. 5, 1931, 231-284). The Strait of Georgia is a great basin connected with the sea by narrow passages which receive water from a number of large rivers, notably the Fraser River. The water from the latter is conserved during the summer and forms a marked upper layer, the epithalassa, which is characterised by low salinity and high temperature. The tempera. ture may be as much as $10^{\circ} \mathrm{C}$. above the water of the sea. Throughout the greater part of the region this epithalassa has a stability which is sufficient to 
resist tidal and wave movement. Abundance of fish food in the form of plankton is present, and the amount is greatest in the region where the most complete mixing of the river and the sea water takes place. The data presented are thought to have an economic bearing upon the fisheries, the establishment of oyster beds, the development of clam beaches, of crab and shrimp industries, and in the location of summer resorts.

\section{Seismological Society of America}

THE last two numbers of Earthquake Notes report the proceedings of the Eastern Section of the Seismological Society of America. Arrangements have been made with the directors of the Society by which it is provided that longer articles read before the Eastern Section shall be published in the Society's Bulletin, the Notes being reserved primarily for notes and news. The recent numbers contain a summary of the papers that were read at the annual meeting of the Section held at Columbia, S.C., on June 11-12, 1931. Most of the papers are devoted to instruments and their records, with one recalling the Charleston earthquake of 1886, some of the effects of which were seen during an excursion to that city. We have also received the last four quarterly numbers (for July 1930-June 1931) of the valuable Bibliography of Seismology issued by the Eastern Section, in which the titles, with occasional brief abstracts, are given of four hundred memoirs dealing with earthquakes.

\section{Library of the Royal College of Surgeons}

ALIST has been published of the volumes in the library of the Royal College of Surgeons (" List of the Transactions, Periodicals, and Memoirs in the Library of the Royal College of Surgeons of England." London : Taylor and Francis, 1931. 2s. 6d.). This is the second edition, the first having been published in 1890 : it contains about twice as many entries as the latter. Perusal of the list shows that the library contains, in addition to the commoner periodicals devoted to medical and allied sciences, a great variety of pamphlets and journals of considerable historical interest, to which access is generally difficult. The list should be of value to librarians and research workers who may desire to refer to papers published in the lesser known or ephemeral journals, as well as to those interested in the history of medicine.

\section{Microlepidoptera of Eastbourne}

In vol. 10 (second supplement) of the Transactions of the Eastbourne Natural History, Photographic and Literary Society for 1931, Mr. Robert Adkin contributes a carefully prepared list of the 'Microlepidoptera' and the more primitive of the larger moths of the Eastbourne district. The list is annotated with many natural history details of considerable interest, and is illustrated by twenty-five excellent photographic plates giving natural-size reproductions of many of the species enumerated. The list is one which will commend itself to anyone interested in the groups of insects dealt with, and is obtainable at the Society's rooms at the Technical Institute, Eastbourne, price 3s. $6 d$. net.

No. 3256, VoL. 129]

\section{Retting of Wool}

Writrng from the Wool Research Department, Massey Agricultural College, Palmerston North, New Zealand, Mr. R. Waters says : "It may be of interest to those engaged in wool research to know that the fibre may be broken down into its constituent cells by retting it in a culture of what appears to be a variety of Bacillus vulgatus, and that this process may conveniently be used to provide cell material for study. The organism apparently does not attack the cells, the material obtained appearing quite normal." Details of the technique employed may be obtained from Mr. Waters.

\section{Announcements}

Prof. E. S. Goodrich, Linacre professor of zoology and comparative anatomy in the University of Oxford, has been selected by the Council of the Linnean Society of London as the recipient of the Linnean Medal, which will be presented to him at the anniversary meeting on May 24.

IT is announced in the Fight against Disease, the quarterly journal of the Research Defence Society, that the Hon. Sir Arthur Stanley has accepted the chairmanship of the Society in succession to the late Lord Knutsford.

IT is announced in Science that Dr. T. W. Stanton, geologist in charge of palæontology and stratigraphy in the United States Geological Survey, has been appointed chief geologist, succeeding Dr. W. C. Mendenhall, who has become director of the Survey.

Messrs. W. and G. Foyle, Ltd., 119 Charing Cross Road, W.C.2, have just circulated a catalogue of medical books offered for sale by them, which many readers should find useful.

A copy of catalogue No. 3, 1932, of Messrs. Oppenheim and Co. (Rare Books), Ltd., 317 A Fulham Road, S.W.10, has reached us. It gives the titles of about 900 works dealing with science, and is particularly strong in sets and long runs of publications of the learned societies.

Applicatrons are invited for the following appointments, on or before the dates mentioned :-A lecturer in education in the University of Manchester-The Registrar, The University, Manchester (April 2). A full-time engineering workshop instructor at the L.C.C. Paddington Technical Institute-The Education Officer (T.1), County Hall, S.E.1 (April 2). An assistant lecturer in pharmacy at the Bradford Technical College-The Principal, Technical College, Bradford (April 6). A professor of physics at University College, Southampton-The Registrar, University College, Southampton (April 16). A chief metallurgist for the Tata Iron and Steel Company, Jamshedpur, India-Tata, Ltd., Capel House, New Broad Street, E.C.2. A head of the department of mechanical and structural engineering and building of the Borough Polytechnic, Borough Road-The Principal, Borough Polytechnic, Borough Road, S.E.1. 